Journal of Applied Pharmaceutical Science Vol. 5 (10), pp. 039-043, October, 2015

Available online at http://www.japsonline.com

DOI: $10.7324 / \mathrm{JAPS} .2015 .501007$

ISSN 2231-3354 (cc) EY-NC-SA

\title{
Effects of isolated compound from Sonneratia caseolaris leaf: a validation of traditional utilization by melanin biosynthesis and antioxidant assays
}

\author{
Enos Tangke Arung ${ }^{1 *}$, Harlinda Kuspradini ${ }^{1}$, Irawan Wijaya Kusuma ${ }^{1}$, Tran Hai Bang ${ }^{2}$, Shuntaro Yamashita ${ }^{3}$, \\ Yoshinori Katakura $^{2}$, Kuniyoshi Shimizu ${ }^{2 * *}$ \\ ${ }^{1}$ Faculty of Forestry, Mulawarman University, Samarinda, 75123, Indonesia. \\ ${ }^{2}$ Faculty of Agriculture, Kyushu University,Fukuoka, 812-8581, Japan. \\ ${ }^{3}$ Graduate School of Systems Life Sciences, Kyushu University, Fukuoka 812-8581, Japan.
}

\section{ARTICLE INFO \\ Article history: \\ Received on: 09/07/2015 \\ Revised on: 09/08/2015 \\ Accepted on: 21/08/2015 \\ Available online: 28/10/2015}

Key words: Sonneratia

caseolaris, melanin

biosynthesis, $\mathrm{H}_{2} \mathrm{O}_{2-}$

scavenging, B16 melanoma

cells, luteolin-7-O- $\beta$-glucoside.

\begin{abstract}
In continuing to search new materials for skin whitening agent from natural resources, we have focused on plants used by Dayak tribe (native people in East Kalimantan, Indonesia) for skin care treatment. The ethanol extract of the leaves of Sonneratia caseolaris showed anti-melanogenesis activity in melanin biosynthesis assays using B16 melanoma cells. By activity-guided fractionation, luteolin-7-O- $\beta$-glucoside (compound 1) was isolated as an active compound. In melanin formation inhibition assay, luteolin-7-O- $\beta$-glucoside showed the inhibitory activity in a dose-dependent manner and reach $44 \%$ of inhibition at $223.2 \mu \mathrm{M}$ with $92 \%$ of cells viability. The compound also showed potent anti-oxidative stress ability with a significant intracellular $\mathrm{H}_{2} \mathrm{O}_{2}$-scavenging activity in $\mathrm{HaCaT}$ cells. These results showed a validation of traditional use for skin care treatment by Dayak tribe in East Kalimantan.
\end{abstract}

\section{INTRODUCTION}

Skin color results from the presence and ratio of several chromophores in the skin. Oxyhaemoglobin (bright red), reduced haemoglobin (luish red and bilirubin (yellow) are found in the small blood vessels of the dermis. Eumelanin (deep brown), phaemelanin (yellow to reddish brown) and sometimes carotenoids (yellow) are the main pigments of the epidermis (Petit and Pierard 2003). Melanin is the major pigment for color of human skin. It is secreted by melanocyte cells in the basal layer of the epidermis (Hearing 2005). Melanin pigments are formed in specialized pigment-producing cells known as melanocytes, which originate in the neural crest during embryogenesis and are distributed throughout the embryo during its development (Sánchez-Ferrer et al., 1995).

Corresponding Authors

*Enos Tangke Arung, Lab. Forest Product Chemistry,

Forestry Faculty, Mulawarman University, Samarinda, Indonesia. Email: tangkearung@yahoo.com

**Kuniyoshi Shimizu, Address: Kyushu University, Fukuoka, Japan.

E-mail: shimizu@agr.kyushu-u.ac.jp ; Phone/Fax: +81-92-642-3002
Melanin biosynthesis occurs in a cascade of enzymatic and spontaneous reactions that convert tyrosine to melanin pigments. The initial and rate-limiting step in melanin synthesis is the hydroxylation of tyrosine to dihydroxy-phenylalanine or DOPA (Yoon et al., 2007). DOPA-oxidation produces a highly reactive intermediate that is further oxidized to form melanin by a free radical-coupling pathway. If free radicals are inappropriately processed in melanin synthesis, hydrogen peroxide $\left(\mathrm{H}_{2} \mathrm{O}_{2}\right)$ is generated, leading to the production of hydroxyl radicals $(\mathrm{HO} \bullet)$ and other reactive oxygen species (Perluigi et al., 2003). In Indonesia, where herbal medicine has been popular, more than 1300 species are known as medicinal plants, called Jamu (Roosita et al., 2008). Jamu has four several functions of medicine such as health care, beauty care (cosmetics), tonics, and bodily protection (Soedarsono and Harini, 2002). Traditional herbal medicines give an interesting, huge unexplored source for development of potential new drugs and cosmetics.

The potential use of traditional herbal medicines for development of new skin-care cosmetics has been emphasized recently (Kiken and Cohen, 2002; Wang et al., 2006). 
A traditional cosmetic product made by Dayak tribe (Native people in Kalimantan island, Indonesia) called "bedak dingin" which sold in traditional market in Samarinda and Pasir cities (Fig. 1), contain some herbal medicines for skin care. Unfortunately, scientific evidences about those herbal medicines have not been known yet. Therefore, in this study we focus on leaves of Rambai Sungai (Sonneratia caseolaris) for its property as skin care by melanin biosynthesis and antioxidant assays.

\section{MATERIALS AND METHODS}

\section{Reagents}

$\mathrm{NaOH}$ and DMSO were purchased from Wako (Osaka, Japan). Trolox and MTT were obtained from Sigma (St. Louis, MO, USA). EMEM was from Nissui Chemical Co (Osaka, Japan). The EDTA was from Dojindo (Kumamoto, Japan). The PDA was from Difco Laboratories (Detroit, USA). The DPPH was from TCI (Tokyo, Japan), Hoechst 33342 (Dojindo, Kumamoto, Japan), BES- $\mathrm{H}_{2} \mathrm{O}_{2}$-Ac (Wako Chemical, Osaka, Japan) and other chemicals were of the highest grade commercially available.

\section{Plant material, extraction and isolation of active compound}

The Rambai Sungai ( $S$. caseolaris) leaves was collected in Samarinda, East Kalimantan, Indonesia, on March in 2008. Voucher specimen (RS-CW-1) was deposited in Wood Chemistry Laboratory, Department of Forest Product Technology, Faculty of Forestry, Mulawarman University. Plant materials were dried at room temperature and powdered. The dried materials (11.33 g) were extracted with EtOH $(100 \mathrm{~mL})$ at room temperature for $48 \mathrm{~h}$. The extract solutions were filtered and concentrated in vacuo, to obtain the crude extracts $(2.09 \mathrm{~g})$. The EtOH extract of Rambai Sungai (1.2 g) was applied to silica gel column (70.4 g of Wakogel C-200, $3.0 \times 30 \mathrm{~cm})$ and eluted with $n$-hexane/EtOAc [10:0 (950 $\mathrm{mL}), 9: 1(200 \mathrm{~mL}), 8: 2$ (300 mL), 7:3 (300 mL), 6:4 (300 mL), 5:5 (200 mL), 4:6 (200 mL), 3:7 (200 mL), 2:8 (200 mL), 1:9 (100 $\mathrm{mL}), 0: 10(100 \mathrm{~mL})$ and EtOAc $/ \mathrm{MeOH} 8: 2(100 \mathrm{~mL}), 6: 4(100$ $\mathrm{mL}), 4: 6(100 \mathrm{~mL}), 2: 8(100 \mathrm{~mL}), 0: 10(200 \mathrm{~mL})]$ to give twenty six fractions (Fr 1 to Fr 26). Based on the melanin inhibitory effect in B16 melanoma cells and analytical HPLC (high performance liquid chromatography), Fr 21 (71 mg) was subjected to isolate the active compound by preparative HPLC (Inertsil Prep-ODS:20 mm i.d. $\mathrm{x} 250 \mathrm{~mm})$ eluting with $\mathrm{MeOH} / \mathrm{H}_{2} \mathrm{O}(0.1 \%$ trifluoroacetic acid, TFA), 60:40, $5 \mathrm{~mL} / \mathrm{min}$, yielded compound 1 (15.3 mg).

The compound 1 was analyzed by NMR at $400 \mathrm{MHz}$ on JNM-AL400 FT NMR spectrometer (Jeo1). The compound 1 was dissolved in DMSO and chemical shift was referred to deuterated solvents. The compound was assigned for ${ }^{1} \mathrm{H}$ and ${ }^{13} \mathrm{C}$.

\section{Determination of melanin content and cell viability on B16 melanoma cells}

A mouse melanoma cell line, B16, was obtained from RIKEN Cell Bank. The cells were maintained in EMEM supplemented with $10 \%$ (v/v) fetal bovine serum (FBS) and 0.09 $\mathrm{mg} / \mathrm{mL}$ theophylline. The cells were incubated at $37{ }^{\circ} \mathrm{C}$ in a humidified atmosphere of $5 \% \mathrm{CO}_{2}$. This assay was determined as described by Arung et al., (2007). Briefly, confluent cultures of B16 melanoma cells were rinsed in phosphate-buffered saline (PBS) and removed from the plastic using $0.25 \%$ trypsin/EDTA. The cells were placed in two plates of 24-well plastic culture plates ( 1 plate is for determining of melanin and other is for cell viability) at a density of $1 \times 10^{5}$ cells/well and incubated for $24 \mathrm{~h}$ in media prior to being treated with the samples. After $24 \mathrm{~h}$, the media were replaced with $998 \mu \mathrm{L}$ of fresh media and $2 \mu \mathrm{L}$ of DMSO was added with or without (control) the test sample at various concentrations $(n=3)$. Arbutin was used as a positive control. The cells were incubated for an additional $48 \mathrm{~h}$, and then the medium was replaced with fresh medium containing each sample. After $24 \mathrm{~h}$, the remaining adherent cells were assayed.

\section{Determination of melanin content in B16 melanoma cells}

The melanin content of the cells after treatment was determined as follows. After removing the medium and washing the cells with PBS, the cell pellet was dissolved in $1.0 \mathrm{~mL}$ of $1 \mathrm{~N}$ $\mathrm{NaOH}$. The crude cell extracts were assayed using a micro plate reader (Bio-Tek, USA) at $405 \mathrm{~nm}$ to determine the melanin content. The results from the cells treated with the test samples were analyzed as a percentage of the results from the control culture.

\section{Cell viability}

Cell viability was determined by use of the micro culture tetrazolium technique (MTT). The MTT assay provides a quantitative measure of the number of viable cells by determining the amount of formazan crystals produced by metabolic activity in treated versus control cells. Culture was initiated in 24-well plates at $1 \times 10^{5}$ cells per well. After incubation, $50 \mu \mathrm{L}$ of MTT reagent [3-(4, 5-dimethyl-2-thiazolyl)-2, 5-diphenyl-2 $H$-tetrazolium bromide in PBS $(5 \mathrm{mg} / \mathrm{mL})]$ was added to each well. The plates were incubated in a humidified atmosphere of $5 \%$ of $\mathrm{CO}_{2}$ at $37^{\circ} \mathrm{C}$ for $4 \mathrm{~h}$. After the medium was removed, $1.0 \mathrm{~mL}$ isopropyl alcohol (containing $0.04 \mathrm{~N} \mathrm{HCl}$ ) was added into the plate, and the absorbance was measured at $570 \mathrm{~nm}$ relative to $630 \mathrm{~nm}$.

\section{Antioxidant (DPPH) assay}

The sample was first dissolved in DMSO and used for the actual experiment at 30 times dilution. The reaction mixture contained $967 \mu \mathrm{L}$ of $60 \mu \mathrm{M}$ DPPH (1, 1-diphenyl-2picrylhydrazyl) in ethanol and $33 \mu \mathrm{L}$ of sample solution in DMSO. After the reaction was carried out at room temperature for 30 minutes, the free radical scavenging activity of the sample was quantified by the decolorization of DPPH at $514 \mathrm{~nm}$ (Arung et al., 2011). Trolox was used as a positive control.

\section{Intracellular $\mathrm{H}_{2} \mathrm{O}_{2}$-scavenging activities}

To determine the $\mathrm{H}_{2} \mathrm{O}_{2}$-scavenging effect of luteolin 7-O$\beta$-glucoside (compound $\mathbf{1}$ ) in cells, immortal human keratinocyte line $(\mathrm{HaCaT})$ was used as cell model. HaCaT cells (Cell Line 
Service, Eppelheim, Germany) were cultured in DMEM supplemented with L-glutamine, $10 \%$ fetal bovine serum and $1 \%$ penicillin/streptomycin antibiotic solution. After being cultured for two days at $37{ }^{\circ} \mathrm{C}$ in a $95 \%$ air $/ 5 \% \mathrm{CO}_{2}$ atmosphere, cells were removed from culture dish by trypsinization and seeded in 96-well $\mu$ Clear Fluorescence Black Plate (\#655090, Greiner Bio-one, Tokyo, Japan) at a density of $2 \times 10^{4}$ cells/well. After one days culturing, medium was changed and cells were continued to be incubated with $20 \mathrm{mM}$ of NAC (N-Acetyl-L-cystein) or with 30 $\mu \mathrm{M}$ of luteolin 7-O- $\beta$-glucoside in culture medium for 6 hours and then for 3 more hours after adding $\mathrm{H}_{2} \mathrm{O}_{2}(640 \mu \mathrm{M}$ or $1000 \mu \mathrm{M})$. Nucleus was stained by Hoechst 33342 and the amount of remained $\mathrm{H}_{2} \mathrm{O}_{2}$ was quantified based on the amount of difluorofluorescein (DFF) released from the reaction of $\mathrm{H}_{2} \mathrm{O}_{2}$ and BES- $\mathrm{H}_{2} \mathrm{O}_{2}$-Ac. The images of each well were acquired from IN Cell Analyzer 1000 (GE Healthcare, Amersham Place, UK) using $360 \mathrm{~nm}$ (Hoechst 33342) and $480 \mathrm{~nm}\left(\mathrm{BES}-\mathrm{H}_{2} \mathrm{O}_{2}\right.$-Ac) excitation filters and monitored through $460 \mathrm{~nm}$ and $535 \mathrm{~nm}$ emission filters, respectively. The images of Hoechst 33342 and $\mathrm{BES}-\mathrm{H}_{2} \mathrm{O}_{2}$ - Ac staining were analyzed using Developer software and resulted data were then applied to Spotfire Decision Site Client 8.2 software for visualizing the results as described previously (Udono et al., 2012). Cells unexposed to $\mathrm{H}_{2} \mathrm{O}_{2}$ were used as controls; cells exposed to $\mathrm{H}_{2} \mathrm{O}_{2}$ with and without pretreatment with NAC were used as positive and negative control, respectively.

\section{Statistical analysis}

The IC50 (median inhibition concentration) is the concentration of the compound that reduces the biological activity by $50 \%$ and determined by JMP Pro ver. 9.0.2 (SAS Institute Japan Ltd). Value was given as geometric means. Differences were considered to be statistically significant when $p<0.05$ and $p<0.01$.

\section{RESULTS AND DISCUSSION}

It is great interest to know whether traditional plants used for skin treatment especially for cosmetic have activities that might be useful in modern formulations. In the present study, we evaluated the ethanol extract of Rambai Sungai (local name) $S$. caseolaris which contain in "bedak dingin" (traditional product) on melanin biosynthesis inhibitory activity in B16 melanoma cells. Beside this assay, the active compound isolated from ethanol extract was also subjected to intracellular $\mathrm{H}_{2} \mathrm{O}_{2}$-scavenging assay using $\mathrm{HaCaT}$ cells to test for anti-oxidative stress activity.

In previous studies, many compounds have been isolated from fruit and leaves of this plant such as: (-)-(R)-nyasol (cishinokiresinol), (-)-(R)-4-O-methylnyasol, 3,8-dihydroxy-6Hbenzo[ $[b, d]$ pyran-6-one, 3-hydroxy-6H-benzo[b,d]pyran-6-one, oleanolic acid, maslinic acid (Wu et al., 2009), luteolin, luteolin 7$O$ - $\beta$-glucoside, benzyl-O- $\beta$-glucopyranoside (Sadhu et al., 2006), but none of them has been proven to have melanin formation inhibitory activity. It is worth to remind that the leaves of $S$. caseolaris, in combination with some herbs, is topically used for skin care by Dayak tribe in "bedak dingin" (Fig. 1). From these fact, we hypothesized the existence of whitening agent that might be useful in modern formulations for skin care in this traditional herbal medicine.

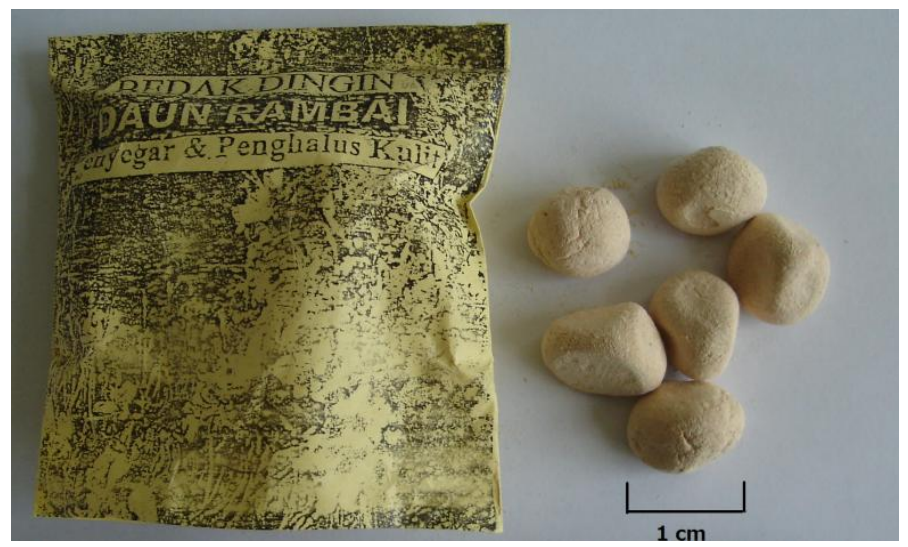

Fig. 1: "Bedak dingin", a traditional skin care product made from S. caseolaris leaves by Dayak tribe which is sold in traditional market in Samarinda and Pasir, East Kalimantan, Indonesia.

In the evaluation of melanin inhibition in B16 melanoma cell, the ethanol extracts of $S$. caseolaris leaves showed melanin inhibition for up to $46 \%$ with less cytotoxicity (15\%) at $100 \mu \mathrm{g} / \mathrm{mL}$ (Fig. 2). The results shown in Fig. 2 and the inhibitory activity of melanin formation in B16 melanoma cells-guided fractionation (data not shown) led us to focus on the active fraction, Fr. 21 to isolate the active compound. As a result of preparative HPLC on active fraction, Fr. 21, compound $\mathbf{1}$ was isolated and identified as luteolin-7- $O$ - $\beta$-glucoside by NMR analysis, compared with standard by analytical HPLC and compared the NMR data with previous report (Kishore et al., 2007). The presence of compound 1 in ethanol extract may affect its inhibition of melanin formation in B16 melanoma cells.

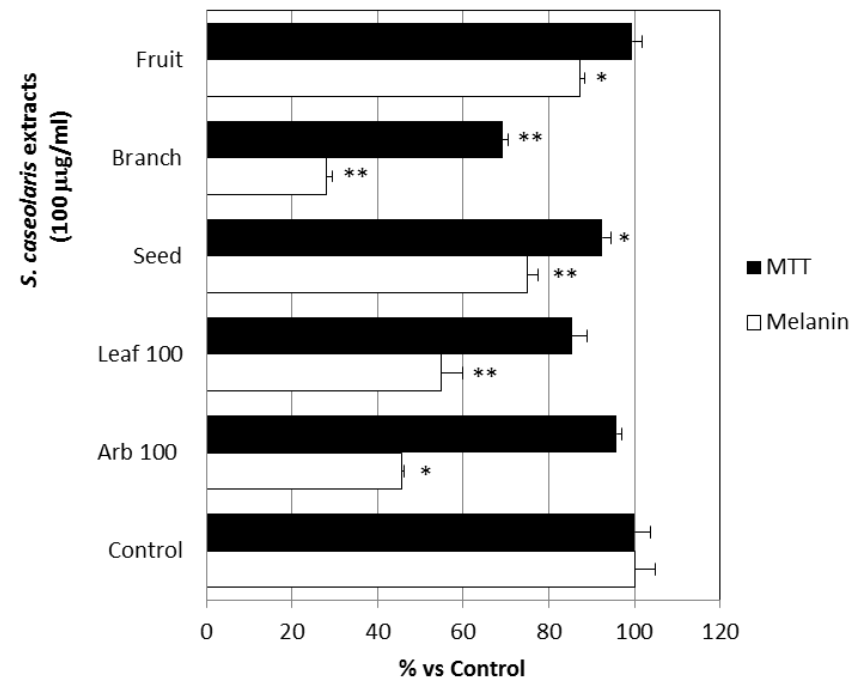

Fig. 2: Melanin formation inhibition effect of ethanol extract prepared from each part of $S$. caseolaris in B16 melanoma cells. Arb $100=$ Arbutin at 100 $\mu \mathrm{g} / \mathrm{mL}$. The values were expressed as mean $\pm \mathrm{SD}, \mathrm{n}=3$. Significant different from the control value (Student's t-test): $P<0.05$ (*), $P<0.01$ (**). 
To confirm the inhibition capacity of the isolated compound we conducted the melanin biosynthesis inhibitory activity for compounds $\mathbf{1}$ using B16 melanoma cells and results were shown in Fig. 3.

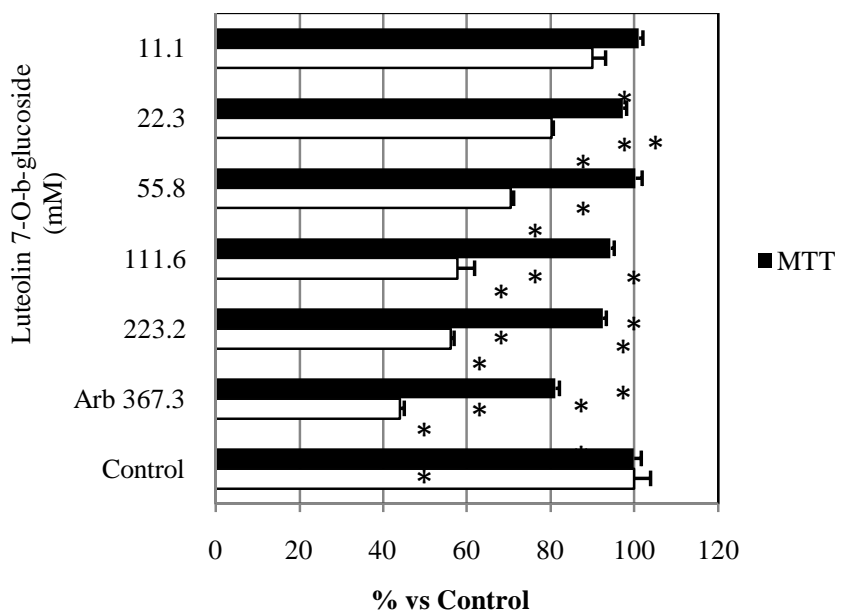

Fig. 3: Melanin formation inhibition effect of luteolin 7-O- $\beta$-glucoside in $\mathrm{B} 16$ melanoma cells [Arb 367.3 = Arbutin at $367.3 \mu \mathrm{M}(100 \mu \mathrm{g} / \mathrm{mL})$ ]. Significant different from the control value (Student's t-test): $P<0.05$ (*), $P<0.01$ (**).

As shown in the Figure, luteolin 7-O- $\beta$-glucoside (compound 1) showed melanin inhibitory activity in a dosedependent manner and reach for $44 \%$ of inhibition at $223.2 \mu \mathrm{M}$ with low cytotoxicity (8\%). Interestingly, isolated luteolin 7-O- $\beta$ glucoside show lower inhibition than its parent extract. This result proposed the existence of more active components in this plant's leaves in the aspect of melanin biosynthesis inhibition. To the best of our knowledge, this is the first report that luteolin-7-O- $\beta$ glucoside has melanin biosynthesis inhibition in B16 melanoma cells. This melanin inhibition may play a part from the effect of luteolin 7-O- $\beta$-glucoside on tyrosinase as reported by Kubo et al., (2000).

Previously, the antioxidant activity of the luteolin-7-O- $\beta$ glucoside by DPPH (Sadhu et al., 2006) and ABTS (BenaventeGarcia et al., 2000) antioxidant assays was reported. In this time, after confirming the in vitro antioxidant activity of the compound 1 using DPPH assay, we ran an $\mathrm{H}_{2} \mathrm{O}_{2}$-scavenging assay using $\mathrm{HaCaT}$ cells as model for testing the intracellular anti-oxidative stress activity of this compound.

In the DPPH assay, the compound showed very strong antioxidant capacity; it even exhibited stronger antioxidant activity than that of trolox, the popular positive control for antioxidant assays. The $\mathrm{IC}_{50}$ value of the compounds 1 was $89 \mu \mathrm{M}, 6$ times higher than trolox's with value of $600 \mu \mathrm{M}$. At cell level, as shown in Fig. 4, compound 1 also showed significant intracellular $\mathrm{H}_{2} \mathrm{O}_{2^{-}}$ scavenging effect. In comparison with control, sample without pretreatment with this compound showed higher level of $\mathrm{H}_{2} \mathrm{O}_{2}$ but the sample which were pre-treated with the compound showed no difference in concentration of this reactive oxygen species. It is also worth to note that the intracellular $\mathrm{H}_{2} \mathrm{O}_{2}$-scavenging capacity of luteolin-7-O- $\beta$-glucoside is similar to that of NAC which has been proven to have anti-oxidative stress in vitro and in vivo (Sadowska et al., 2007), even at much lower concentration.

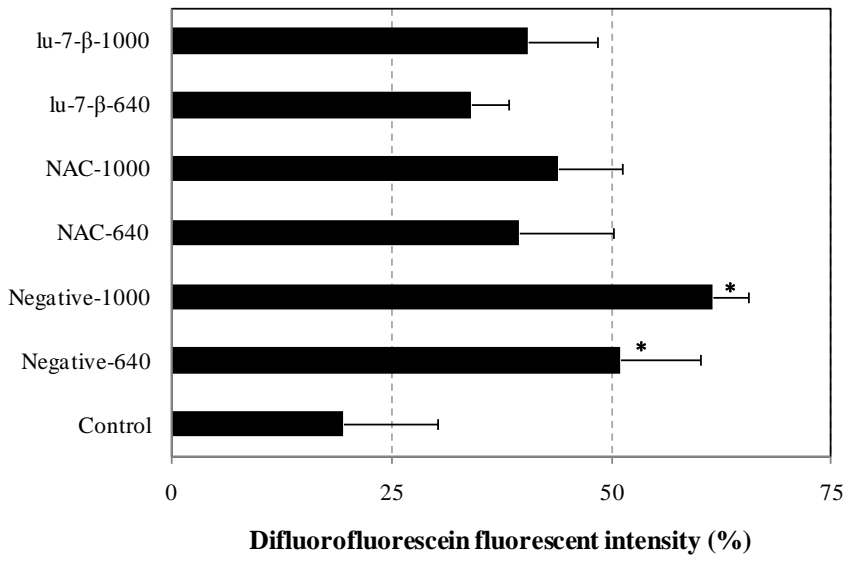

Fig. 4: Intracellular $\mathrm{H}_{2} \mathrm{O}_{2}$ concentration (expressed as difluorofluorescein fluorescent intensity) in $\mathrm{HaCaT}$ cells with pre-treatment of luteolin-7-O- $\beta$ glucoside (lu-7- $\beta$ ); the numbers attached after samples' name were the concentration in $\mu \mathrm{M}$ of $\mathrm{H}_{2} \mathrm{O}_{2}$ added to each assay's well; N-Acetyl-L-cystein (NAC) was used as positive control while $\mathrm{H}_{2} \mathrm{O}_{2}$ was used for negative control. The values were expressed as mean $\pm \mathrm{SD}, \mathrm{n}=2$; Significantly different from the control value (Student's t-test): $P<0.05(*)$; lower bar showed better scavenging effect.

Skin is a one of the major target of oxidative stress caused by reactive species (RS), including reactive oxygen species and reactive nitrogen species. RS are major and significant contributors to skin hyperpigmentation and skin aging (Choi et al., 2008). It has been generally believed that agents having antioxidant activity show anti-aging, whitening, and antiinflammatory activities (Kim et al., 2008). By taking into consideration about the results of antioxidant activities of against DPPH and intracellular $\mathrm{H}_{2} \mathrm{O}_{2}$-scavenging, luteolin-7-O- $\beta$ glucoside should be a good candidate for skin-whitening and antioxidant medication.

\section{CONCLUSION}

In this study, the ethanol extract of $S$. caseolaris leaves demonstrated the inhibitory activities on melanin formation in B16 melanoma cells. One of the active compounds was isolated and identified as luteolin-7-O- $\beta$-glucoside. The subsequent assays for inhibition of melanin formation and anti-oxidative stress validated the traditional used of $S$. caseolaris leaves by Dayak tribe, a native people in East Kalimantan.

\section{ACKNOWLEDGEMENT}

This research supported by Directorate General of Higher Education, Indonesia Ministry of National Education with grant no: 500/SP2H/PL/2011.

\section{REFERENCES}

Arung ET, Shimizu K, Kondo R. Structure-activity relationship of prenyl-substituted polyphenols from Artocarpus heterophyllus as 
inhibitors of melanin biosynthesis in cultured melanoma cells. Chemistry and Biodiversity, 2007; 4, 2166-2171.

Arung ET, Furuta S, Ishikawa H, Kusuma IW, Shimizu K, Kondo R. Anti-melanogenesis properties of quercetin- and its derivativerich extract from Allium cepa. Food Chemistry, 2011; 124, 1024-1028.

Benavente-Garcia O, Castillo J, Lorente J, Ortuno A, Del Rio DA. Antioxidant activity of phenolics extracted from Olea europaea L. leaves. Food Chemistry, 2000; 68, 457-462.

Choi MY, Song HS, Hur HS, Sim SS. Whitening activity of luteolin related to the inhibition of cAMP pathway in alpha-MSHstimulated B16 melanoma cells. Archive Pharmcology Research, 2008; $31,1166-1171$.

Hearing VJ. Biogenesis of pigment granules: a sensitive way to regulate melanocyte function. Journal of Dermatology Science, 2005; 37, $3-14$

Kiken DA, Cohen DE. Contact dermatitis to botanical extracts. American Journal of Contact Dermatitis, 2002; 13, 148-152.

Kim Y J, Kang K S, Yokozawa T. The anti-melanogenic effect of pycnogenol by its anti-oxidative actions. Food Chemical and Toxicology, 2008; 46, 2466-2471.

Kishore K. C, Arifullah M, Gayathri D, Rama G. G, Sathees C. R. Phytochemical and antimicrobial studies of methyl angolensate and luteolin-7-O-glucoside isolated from callus cultures of Soymida febrifuga. International Journal of Biomedical Science, 2007; 3, 269-278

Kubo I, Kinst-Hori I, Chaudhuri SK, Kubo Y, Sánchez Y, Ogura T. Flavonols from Heterotheca inuloides: tyrosinase inhibitory activity and structural criteria. Bioorganic and Medicinal Chemistry, 2000; $8,1749-1755$

Perluigi M, De Marco F, Foppoli C, Coccia R, Blarzino C, Marcante ML, Cini C. Tyrosinase protects human melanocytes from ROSgenerating compounds. Biochemical and Biophysical Research Communication, 2003; 305, 250-256.

Petit I, Pierard GE. Skin-lightening products revisited. International Journal of Cosmetic Science, 2003; 25, 169-181

Roosita K, Kusharto CM, Sekiyama M, Fachrurozi Y, Ohtsuka R. Medicinal plants used by the villagers of a Sundanese community in West Java, Indonesia. Journal of Ethnopharmacology, 2008; 115, 72-81
Sánchez-Ferrer A, Rodrígez-López JN, García-Carmona F. Tyrosinase: a comprehensive review of its mechanism. Biochimia Biophysic Acta, 1995; 1247, 1-11

Sadhu S.K, Ahmed F, Ohtsuki T, Ishibashi M. Flavonoids from Sonneratia caseolaris. Journal of Natural Medicine, 2006; 60, 264-265.

Sadowska A.M, Manuel-y-Keenoy B, De Backer W.A. Antioxidant and anti-inflammatory efficacy of NAC in the treatment of COPD: Discordant in vitro and in vivo dose-effects: A review, Pulmonary Pharmacology \& Therapeutics, 2007; 20, 9-22

Soedarsono RS, Harini SR. Jamu as traditional medicine in Java, Indonesia. South Pacific Study, 2002; 23, 1-9

Udono M, Kadooka K, Yamashita S, Katakura Y. Quantitative analysis of cellular senescence phenotypes using an imaging cytometer. Methods, 2012; 56, 383-388

Wang KH, Lin RD, Hsu FL, Huang YH, Chang HC, Huang HC, Lee MH. Cosmetic applications of selected traditional Chinese herbal medicines. Journal of Ethnopharmacology, 2006; 106, 353-359.

Wu S.B, Wen Y, Li X.W, Zhao Y, Zhao Z, Hu J.F. Chemical constituents from the fruits of Sonneratia caseolaris and Sonneratia ovata (Sonneratiaceae). Biochemical Systematics and Ecology, 2009; 37, 1-5

Yoon JH, Shim JS, Cho Y, Baek NI, Lee CW, Kim HS, Hwang JK. Depigmentation of melanocytes by isopanduratin $A$ and 4hydroxypanduratin A isolated from Kaempferia pandurata RoxB. Biological and Pharmaceutical Bulletin, 2007; 30, 2141-2145.

\section{How to cite this article:}

Enos Tangke Arung, Harlinda Kuspradini, Irawan Wijaya Kusuma, Tran Hai Bang, Shuntaro Yamashita, Yoshinori Katakura, Kuniyoshi Shimizu. Effects of isolated compound from Sonneratia caseolaris leaf: a validation of traditional utilization by melanin biosynthesis and antioxidant assays. J App Pharm Sci, 2015; 5 (10): 039-043. 